\title{
A comparison of pre-European settlement forest characterization methodologies
}

\author{
by Matthew Betts ${ }^{1}$ and Judy Loo $^{2}$
}

\begin{abstract}
The characterization of "natural" or "presettlement" forest has become a relatively common practice in Canada as forest managers strive to put into practice concepts of sustainable forest management. Various methods have been developed to undertake such characterizations, leading to confusion about how to define "presettlement forest" and uncertainty over the approach that will best serve as a basis for management. We report on two methods of presettlement forest characterization: the "Witness Tree" and the "Potential Forests" approaches. We compare results from these approaches to the existing forest composition in the Fundy Model Forest, New Brunswick. Both approaches indicate a decline in the predominance of tolerant hardwood and eastern cedar since presettlement. However, the Potential Forests approach consistently suggests much higher presettlement frequencies of spruce (Picea spp.) and, in most cases, pine (Pinus spp.) than the Witness Tree method. Differences between frequencies of tree species estimated by the two methods probably result from biases associated with both methods and the different scales of reporting. If used critically, the combined use of both sets of presettlement forest information will allow managers to determine the historical frequency of individual tree species and forest communities. Such information will provide some guidance in maintaining the diversity of native species and community types.
\end{abstract}

Keywords: presettlement forest, ecological land classification, Witness Tree method, Potential Forests, forest management, biodiversity

La caractérisation des forêts « naturelles » ou «pré-coloniales » est devenue une pratique relativement commune au Canada compte tenu que les aménagistes forestiers cherchent à mettre en pratique les concepts de l'aménagement forestier durable. Diverses méthodes ont été mises au point pour établir de telles caractérisations, entraînant de la confusion autour de la définition de « forêt pré-coloniale » et de l'incertitude au niveau de l'approche qui servira le mieux de base d'aménagement. Nous faisons état de deux méthodes de caractérisation de la forêt pré-coloniale : l'approche «Arbre témoin » et l'approche « Forêts potentielles ». Nous comparons les résultats de ces approches avec la composition de la forêt existante dans la forêt modèle de Fundy au Nouveau-Brunswick. Les deux approches indiquent un déclin de la prédominance des feuillus tolérants et du thuya de l'Est depuis l'ère pré-coloniale. Toutefois, l'approche Forêts potentielles suggère de façon constante des fréquences plus importantes avant la colonisation d'épinette (Picea spp.) et, dans la plupart des cas, de pin (Pinus spp.) que ne le fait la méthode de l'Arbre témoin. Les différences entre les fréquences des espèces d'arbres estimées par les deux méthodes découlent probablement des biais associés aux deux méthodes et aux différentes échelles de compilation. Si ces méthodes sont utilisées de façon critique, l'utilisation combinée de ces deux séries d'information sur les forêts pré-coloniale permettra aux aménagistes de déterminer la fréquence historique de chacune des espèces d'arbres et des communautés forestières. Une telle information procurera une certaine direction vers le maintien de la diversité des espèces indigènes et des types de communautés.

Mots-clés: forêt pré-coloniale, classification écologique du territoire, méthode de l'Arbre témoin, Forêts potentielles, aménagement forestier, biodiversité

\section{Background}

Forest managers and scientists commonly define "sustainable forest management" in relation to concepts of the "natural" forest. Practitioners of sustainable forest management have been advised to mimic the spatial scale of natural disturbances (e.g., succession, insects, fire, and weather) (Woodley and Forbes 1997, Hébert and Boutin 1998), the structures found in unharvested stands (e.g., dead wood, large trees) (Schnitzler and Borlea 1998), and the tree species and community composition of forest undisturbed by humans (Hansen et al. 1991, Loo 1994). The difficulty is in defining the term "natural." In developing a set of criteria and indicators for sustainable forest management, the Canadian Council of Forest Ministers (CCFM 1995) adopted the view that the "historical" condition of the forest is the best baseline: "Percentage and extent, in area, of forest

${ }^{1}$ Current Address: Greater Fundy Ecosystem Research Group, Hugh John Flemming Forestry Centre, 1350 Regent St., Fredericton, New Brunswick E3C 2G6. E-mail: mbetts@unb.ca

${ }^{2}$ Current Address: Natural Resources Canada, Canadian Forest Service - Atlantic Forestry Centre, P.O. Box 4000, Fredericton, NB, E3B 5P7.

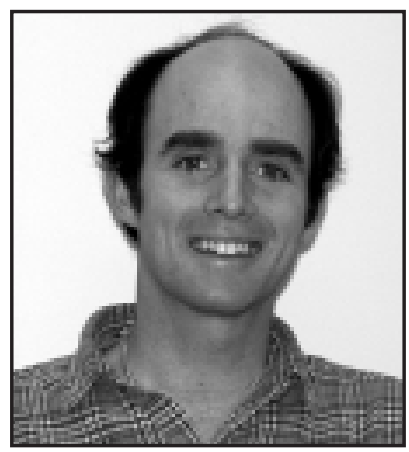

Matthew Betts

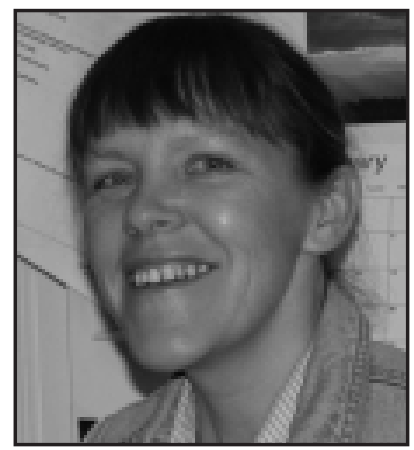

Judy Loo types relative to the historical condition and total forest area" (Criterion 1.1.1). However, they did not provide a definition of "historical."

In 1996, the Fundy Model Forest (FMF) adopted the CCFM's Criteria and Indictors process as the basis for locallevel monitoring (Etheridge et al. 1999). Fifty-three of the CCFM indicators were selected and refined to fit within the context of the FMF. The criterion relating to historical condition of the 
forest (CCFM 1.1.1) was restated as: "Percentage and extent in area of forest community and age class by Ecological Land Classification (ELC), relative to pre-European settlement condition and total forest area" (Etheridge et al. 1999)(emphasis added).

Two attempts have been made to characterize the historical forest composition of the FMF region. Lutz (1997) examined early land surveyors' records for original land grants (mostly between 1785 and 1820) to identify the relative abundance of tree species or genera. Using almost 4000 individual witness tree records, Lutz provided an estimate of the frequency and distribution of tree species (or genus). Zelazny et al. (1997) used the ecosite classification from the New Brunswick ELC (NBDNRE 1996) and the 1983 forest inventory data to estimate the frequency of "historical" forest community types. Called "potential forest types," these are commonly used to describe presettlement forest conditions.

These separate approaches have led to some confusion about how to define presettlement forest, and which method will best serve as a basis for guiding management decisions. North American forest managers have increasing access to presettlement characterizations (Hessburg et al. 1999, Jackson et al. 2000, Dyer 2001, Friedman et al. 2001) but, if they are to use this information effectively, the basic assumptions, strengths, and weaknesses of these approaches must be examined. In this paper, we summarize and evaluate these two very different approaches to presettlement characterization. Results of both methods are related to present-day forest cover in the context of the New Brunswick ELC (NBDNRE 1996).

\section{Ecological Land Classification}

Understanding the New Brunswick ELC is critical to interpretation of both presettlement methodologies. The ELC is a hierarchical system that categorizes the spatial distribution of terrestrial ecosystems by defining a range of factors that influence their distribution across many scales (NBDNRE 1996). At the top of the hierarchy, ecoregions are defined by elevation and climatic variables (NBDNRE 1996) (Fig. 1). At the next level, ecodistricts are a function of broad-scale elevation, geological features, slope and aspect. At a finer scale, ecosites are defined by elevation and slope classes, soil type and drainage, and associated forest types (Zelazny et al. 1997) (Fig. 2).

\section{Presettlement Forest Methodologies \\ The Witness Tree method}

In order to mark the position of early settlers' land grant boundaries on the ground, surveyors in the late 1700s and early $1800 \mathrm{~s}$ blazed and noted the species, or at least genus, of witness trees at regular intervals along the sides and at the corners of each grant. This process yields much more information in heavily settled counties than in more sparsely settled ones. Kings County was settled primarily by Loyalists between 1785 and 1820 and was one of the more heavily settled counties in New Brunswick. Witness tree records in the county, potentially, provide a "snapshot" of tree species frequency at the end of the $18^{\text {th }}$ century.

New Brunswick surveyors were not instructed to inscribe information on the surface of the majority of trees, a practice that may have biased previous witness tree accounts (Bourdo 1956). Corner trees were not used to assist in re-identifying points in later surveys, as was the practice in American General

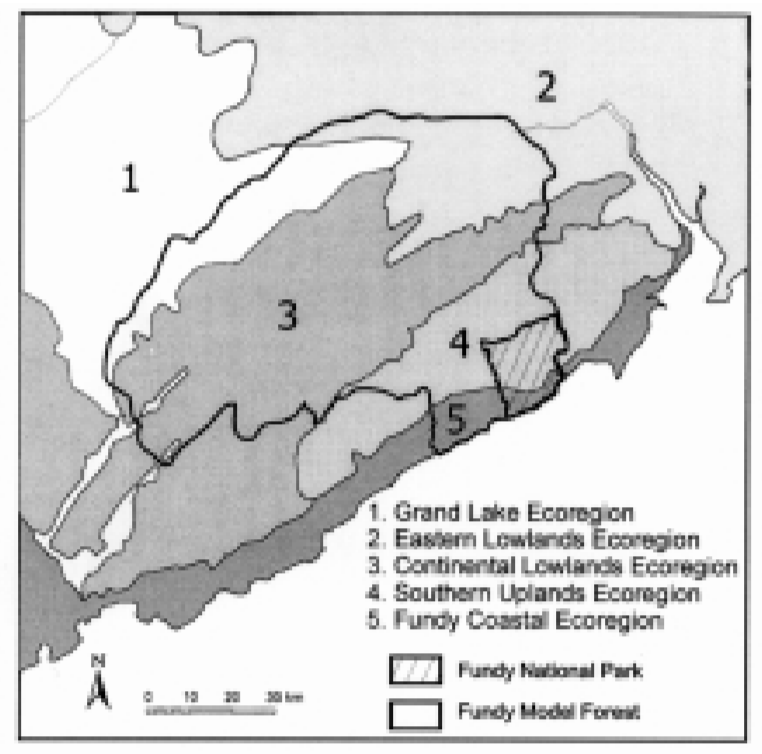

Fig.1. Ecoregions encompassing the Fundy Model Forest

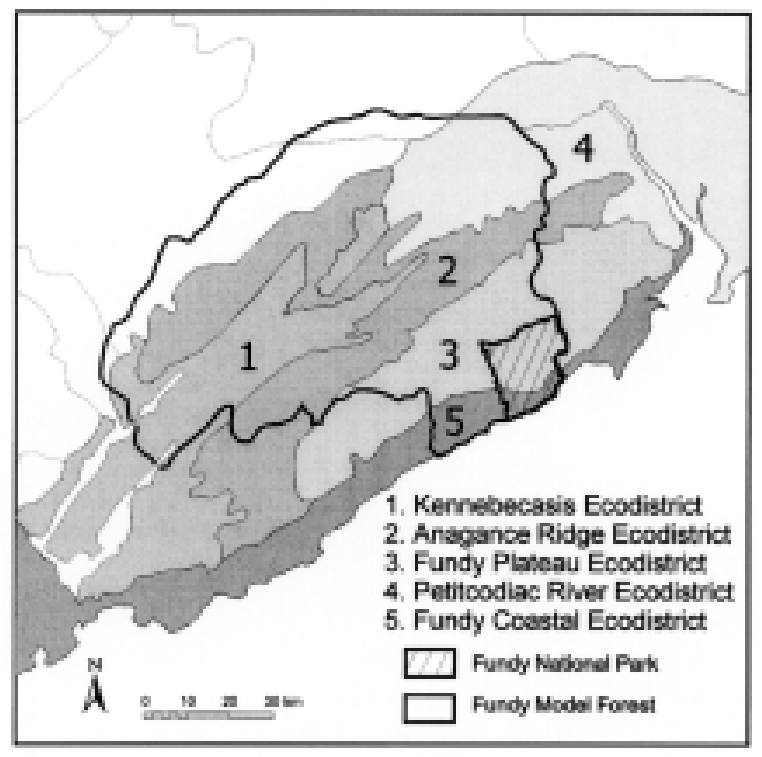

Fig. 2. Ecodistricts of the Fundy Model Forest

Land Office surveys (Bourdo 1956). Although there may have been some bias in selecting junction witness trees, it is expected that there would be no bias in the case of line trees because no information was gleaned from or inscribed on these.

There are several advantages to the Witness Tree survey method for determining presettlement forest conditions. For counties that had a high and relatively uniform settlement density in the $19^{\text {th }}$ century, before much forest harvest occurred, and for areas of relatively stable forest having primarily gap replacement rather than catastrophic disturbance history, the Witness Tree method provides a relatively bias-free and extensive sample of presettlement tree species composition. Furthermore, tree species (or genus) 
frequency can be related to soil type, drainage, aspect, and slope class (ecosite) because exact locations of the witness trees were recorded. The method also reports actual historical data unlike other approaches for estimating historical condition.

Several disadvantages exist to the use of witness tree accounts. First, several possible biases exist. Lutz (1997) noted two potentially serious sources of bias in the witness tree records that may have resulted in underestimation of white pine (Pinus strobus). White pine was the only species that was already being harvested at the time the Kings County land was granted. This probably influenced the frequency of pine on the ground. Also, there was a high demand at that time by the British navy for masts and spars. Large white pine trees were marked with the "King's arrow" effectively reserving them for the navy. Lutz (1997) speculated that surveyors may have avoided blazing these trees because the new landowners would have no control over their removal.

Second, for some witness trees, only genus was recorded. This ambiguity is of particular concern to managers because of the widely different silvics of some species within the same genus (sugar maple [Acer saccharum] vs. red maple [Acer rubrum], jack pine [Pinus banksiana] vs. red pine [Pinus resinosa] and white pine, yellow birch [Betula alleghaniensis] vs. white birch [Betula papyrifera], and white spruce [Picea glauca] vs. red spruce [Picea rubens] and black spruce [Picea mariana]) (Burns and Honkala 1990). Third, records indicate individual trees, not community types. In some ecosites, small witness tree sample sizes offer little power for estimating the overall community composition. Finally, this historical approach provides a "snapshot" but does not offer a method to determine how the forest might have changed naturally over 200 years in the absence of human intervention.

\section{The Potential Forests approach}

Zelazny et al. (1997) defined "potential vegetation" as the stand composition and pattern of forest types that would have existed before farming, harvesting, and fire and insect suppression began to dominate local forest dynamics.

The Potential Forests approach is based upon the New Brunswick Ecological Land Classification. By examining enduring features of the landscape (i.e., climate, topography, bedrock, and soils), Zelazny et al. (1997) attempted to reveal the inherent pattern of forest distribution. This, combined with natural disturbance regimes such as fire, windstorms, insects, disease, and individual tree fall, creates the presettlement forest pattern across landscapes.

The ELC group used the ecosite delineation process to estimate the characteristics of presettlement forest. Four geographical information system (GIS) map layers were used: (i) elevation and slope classes, (ii) soil type and soil drainage (Colpitts et al. 1995), (iii) forest cover types (NBDNRE 1986), and (iv) the existing Ecological Land Classification for ecodistricts (NBDNRE 1996). Each of these data layers was divided into classes on the basis of striking differences in occurrences of certain stand types in relation to geomorphological features. For example, Zelazny et al. (1997) noted that black spruce stands disappear at a slope of $20 \%$.

Ecosites were the result of all classes of the four biotic and abiotic data layers being combined to form discreet combinations. For example, all sites classed as ecosite 3 are "wet, nutrientrich hardwood," whereas “dry, nutrient-poor softwood” sites are characteristic of ecosite 1 . All nine of these ecosites, along with sub-categories to denote special conditions, (e.g., "c" for calcareous), make up the edatophic grid (Fig. 3).

Once ecosites had been delineated, the 1983 forest inventory data were stratified into seven "forest communities." This was seen as practical for forest management purposes. The seven communities are pine (PINE), black spruce (BS), spruce/fir (SPBF), balsam fir (Abies balsamea) (BF), eastern cedar (EC), mixedwood of tolerant species (MXWD), and tolerant hardwood (TOHW). Photo-interpreted forest inventory data from across New Brunswick were used to determine the frequency of the seven forest communities within each ecodistrict by ecosite. This allowed the development of ecosite-forest community associations.

In order to compensate for human-induced changes that have occurred since European settlement, Zelazny et al. (1997) made several adjustments. First, intolerant hardwood (IH) communities were not included in the analysis as a forest community group. The reasoning was that this community type does not display a strong relationship with environmental variables. The ELC group argued that this is an early successional community that is likely to be a reflection of human disturbance. Second, stands that had grown up on old fields were not included in the analysis. White spruce, poplar, balsam fir, and white birch are predominant species on old fields in the Maritimes (Rowe 1959, Loucks 1962). As the presence of this combination of species reflects agricultural disturbance rather than enduring features, they would have biased the characterization of presettlement forest.

The final result of the Potential Forests approach was a series of "potential forest communities" (e.g., BS, TH, MXWD etc.) by ecosite and ecodistrict based on three factors: (1) ecosite classification, (2) the 1983 forest inventory, and (3) forest community adjustments to compensate for known human disturbance such as farming.

There are several strengths of the Potential Forests approach. It provides a characterization of presettlement forest communities based primarily on enduring features such as soil and climate rather than ephemeral features such as individual trees. Thus, it defines a frequency distribution of community types for a given ecosite. This fits with the concept of dynamic (Botkin 1990), rather than stable or static forest communities (Clements 1936). This also allows forest managers some flexibility in managing for the frequency of forest communities. Second, the Potential Forests approach is spatially explicit and can thus predict the spatial distribution of presettlement forest across the Fundy Model Forest.

However, there are also several disadvantages to the Potential Forests approach. First, this method relies on the 1983 forest inventory to develop ecosite-forest community associations. Although some adjustments were made to compensate for human disturbance (removal of old fields and intolerant hardwood from the analysis), it is certain that many other human activities have influenced forest composition since European settlement. For example, tree species such as white pine, red spruce, eastern hemlock (Tsuga canadensis), and tamarack (Larix laricina) have been selectively removed from New Brunswick forests over the past 200 years (Lutz 1997). Budworm suppression may have led to extended longevity of spruce-fir stands, allowing these species to regenerate over a larger area (Blais 1983). Furthermore, lumping all native tree species into seven "community 


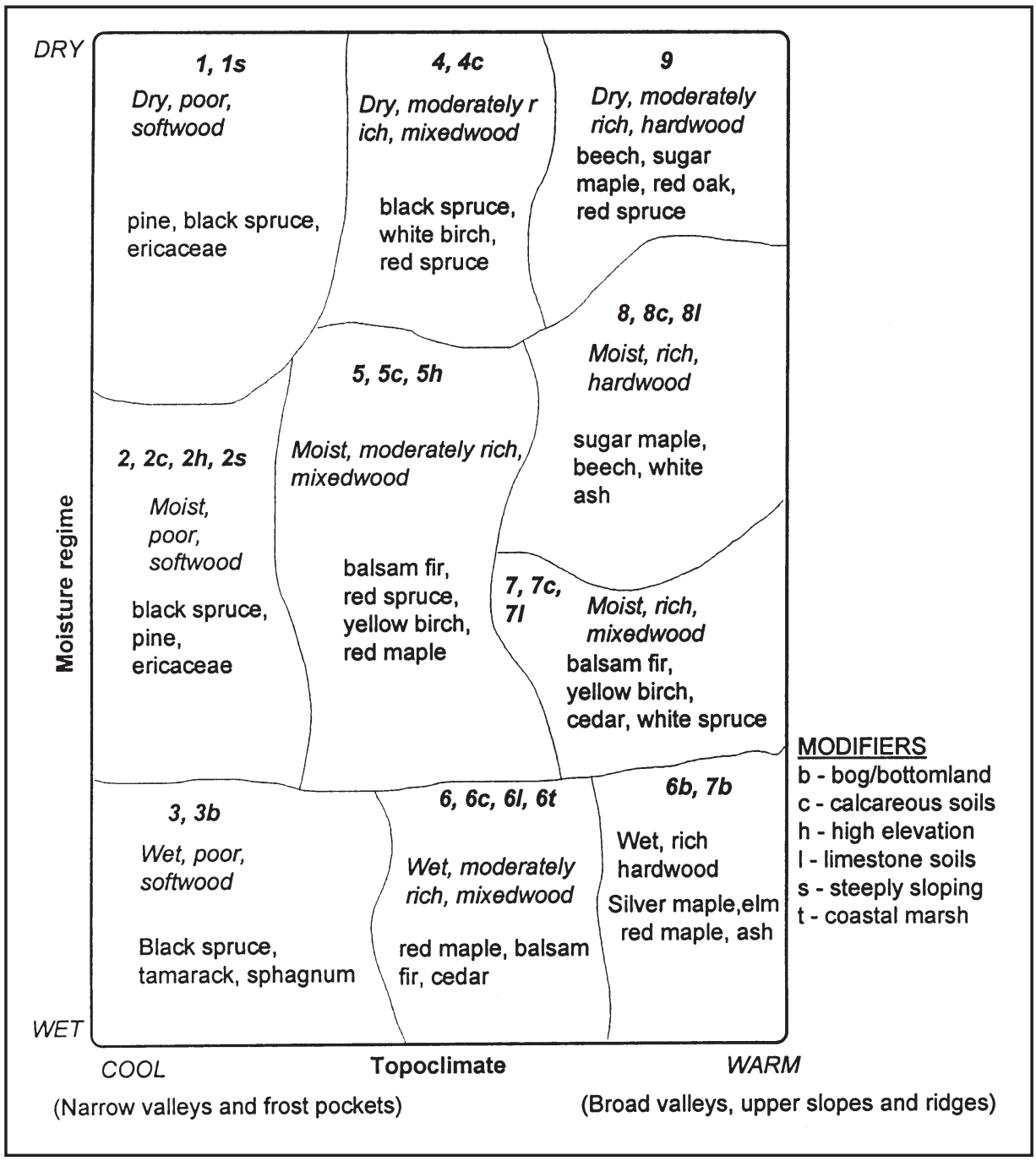

Fig. 3. Edatophic grid showing ecosite classification. (Source: NBDNRE 1996)

types" does not allow the level of precision that is required to estimate the frequency of less common or less merchantable species such as eastern hemlock and American beech (Fagus grandifolia). Zelazny et al. (1997) tried to offset this problem by providing predicted species frequencies by ecosite. If Potential Forests predictions are to be used in landscape-level management, it will be important to consider these species frequency guidelines.

Finally, although the ELC group emphasized the strong influence of natural disturbance on forest composition, it was not considered as part of the presettlement forest analysis. A fire model (FireNB) (Remsoft Inc. 1996) was used to determine fire return frequency. However, return frequency was not included as a factor affecting community type. The predominant type of disturbance in most of the FMF ecodistricts may have been individual tree fall (gap-dynamics) (Seymour 1992, Woodley and Forbes 1997), but it is highly probable that fire, insect infestation, and blowdown acted as significant influences on the characteristics of presettlement forests (Wein and Moore 1977, Zelazny et al. 1997). The removal of all early successional stand types (intolerant hardwood) from the analysis probably underemphasized the role of stand-replacing disturbances.

\section{Methods: Comparing the Results of Two Methodologies}

It is difficult to compare the results of Lutz (1997) and Zelazny et al. (1997) because there are substantial differences in the data sources and in how the data were used in estimating presettlement forest composition (Table 1). Nevertheless, to serve as the basis for a much-needed discussion on the role of presettlement forest characterization in guiding forest management decisions, we have attempted a rough comparison of the results of each study with present-day forest. The comparison was carried out as follows:

1. Species and genera examined by Lutz (1997) were grouped into community types. Ash, maple, birch, and beech were combined to form a single Tolerant Hardwood (TH) category. It is unlikely that all birch and maple were the tolerant/partly tolerant species of sugar maple and yellow birch. However, because Zelazny et al. (1997) did not include intolerant hardwoods in their analysis, this assumption does not result in an unfair comparison.

2. Zelazny et al.'s (1997) community types SPBF (spruce-balsam fir) and BS (black spruce) were combined and compared to Lutz's (1997) "spruce” category (Table 2). One potential difficulty is the comparison of Lutz's species cate- 


\begin{tabular}{|c|c|c|}
\hline & Witness Tree Approach & Potential Forests Approach \\
\hline \multirow[t]{2}{*}{ Data sources } & $\begin{array}{l}\text { Surveyors' witness trees for } \\
\text { presettlement composition }\end{array}$ & $\begin{array}{l}\text { ELC, } 1984 \text { FDS data (photo interpreted) for presettlement } \\
\text { composition }\end{array}$ \\
\hline & $\begin{array}{l}\text { FDS permanent sample plot (PSP) } \\
\text { data for present species composition }\end{array}$ & FDS aerial photo data (1993) for present species composition \\
\hline Sampling intensity & $\begin{array}{l}\text { High for Ecoregion } 5 \text { ( } 3342 \text { witness trees), } \\
\text { low for Ecoregions } 3 \text { (245) and } 4 \text { (92) }\end{array}$ & $\begin{array}{l}\text { Estimates were based on photo-interpreted stands and } \\
\text { then "adjusted" based on } 3461 \text { ground plots. }\end{array}$ \\
\hline Scale of analysis & Individual species or genus & Community \\
\hline $\begin{array}{l}\text { Scale of comparison } \\
\text { (landscape level) }\end{array}$ & Ecoregion & Ecodistrict \\
\hline $\begin{array}{l}\text { Scale of reporting } \\
\text { (site level) }\end{array}$ & Ecosite & Ecosite \\
\hline
\end{tabular}

Table 2. Species groups (Lutz 1997), equivalent community types (Zelazny et al. 1997) and the community types used for comparative analysis

\begin{tabular}{|c|c|c|}
\hline $\begin{array}{l}\text { Witness Tree/ FDS } \\
\text { survey categories } \\
\text { (Lutz 1997) }\end{array}$ & $\begin{array}{l}\text { Potential Forest } \\
\text { community types }\end{array}$ & $\begin{array}{l}\text { New community } \\
\text { types used for } \\
\text { comparison }\end{array}$ \\
\hline $\begin{array}{l}\text { Birch }+ \text { beech }+ \text { maple }+ \\
\text { sugar maple } 5+\text { ash }+ \\
\text { butternut }+ \text { ironwood }+ \\
\text { yellow birch }\end{array}$ & $\mathrm{TH}$ & $\mathrm{TH}$ \\
\hline Fir & $\mathrm{BF}$ & Fir \\
\hline Spruce & $\mathrm{SPBF}+\mathrm{BS}$ & Spruce \\
\hline Cedar & $\mathrm{EC}$ & Cedar \\
\hline $\begin{array}{l}\text { Poplar + elm + alder + } \\
\text { hemlock + tamarack + } \\
\text { white birch + willow + } \\
\text { "white maple" }\end{array}$ & N/A & Other \\
\hline $\begin{array}{l}\text { White pine }+ \text { pine }+ \\
\text { "yellow pine" } 6\end{array}$ & PINE & Pine \\
\hline $\begin{array}{l}\text { Unknown hardwood, } \\
\text { white birch, poplar }\end{array}$ & N/A & Intolerant Hardwood \\
\hline N/A & MXWD & Mixedwood \\
\hline
\end{tabular}

Note: Tolerant Hardwood (TH), balsam fir (BF), spruce-balsam fir (SPBF), black spruce (BS), pine (PINE), mixedwood (MXWD).

gories with Zelazny et al.'s tolerant mixedwood (MXWD) community type. It is unknown how many witness trees existed in mixedwood communities because no surveyors' records were kept about broad community types.

3. The ecodistricts (used by Zelazny et al. 1997) were grouped into ecoregions (Lutz used only ecosites and ecoregions in

\footnotetext{
${ }^{4}$ Lutz (1997) analyzed 20 species from the surveyors' records. Only the commonly recorded ones are listed here.

5 "White maple" was not included in this category because this was probably a surveyor reference to either silver maple or red maple.

${ }^{6}$ Lutz (1997) found several species names for witness trees that are different from current species names. In these cases, he grouped records into a single category by genera.
}

Table 3. Ecoregions and equivalent ecodistricts. In the Fundy Region, all ecodistricts are nested within ecoregions

\begin{tabular}{ll}
\hline Ecoregion & Equivalent Ecodistrict(s) \\
\hline 5, Continental Lowlands & 31, Kennebecasis and 29, Anagance Ridge \\
4, Fundy Coastal & 32, Fundy Coastal \\
3, Southern Uplands & 12, Fundy Plateau \\
\hline
\end{tabular}

his analysis) (Table 3). In all cases, ecodistricts are fully nested in ecoregions.

4. Because Lutz's analysis was restricted to Kings County (Ecoregion 5 - Continental Lowlands, Ecoregion 4 - Fundy Coastal, and Ecoregion 3 - Southern Uplands), comparisons could only be performed for these portions of the Fundy Model Forest, constituting about two-thirds of the area. For the purposes of this analysis, only Ecoregion 5, the ecoregion with the most witness tree samples, was examined.

5. All species and community types from Lutz (1997) that did not fit into community group categories were put into the "other" category on frequency graphs (Table 2).

6. Potential Forests and Witness Tree methods report at different scales. Potential Forests data are reported at the scale of the forest community group, but the Witness Tree method is reported at the scale of the individual tree species or genus. Despite our attempt to group witness tree data into community groups, direct comparison is problematic. Thus, to allow for comparability between the two presettlement data sets and the present forest, we used two separate approaches to determine current forest composition by ecosite (Fig. 4).

For comparison with witness tree data, species basal area data from 1986-1993 Forest Development Survey (FDS) timber cruise lines and Permanent Sample Plots (PSPs) $(\mathrm{n}=957)$ were summarized by percent frequency for each ecosite. We considered basal area, rather than stem density the measure most comparable to colonial surveys. This is because number of stems is a poor measure of the number of mature trees in a stand, as many saplings die during the stem exclusion phase of stand development (Oliver and Larson 1996). These small trees would not have been used in witness tree surveys. These basal area frequencies were then lumped into community groups in the 


\begin{tabular}{|c|c|}
\hline Witness Tree Survey & Potential Forests \\
\hline $\begin{array}{l}\text { 1. Data obtained for live witness trees on } \\
\text { lines and corners of surveyor routes }\end{array}$ & $\begin{array}{l}\text { 1. Ecosites developed from climate, soils, } \\
\text { slope and } 1983 \text { forest data }\end{array}$ \\
\hline $\begin{array}{l}\text { 2. Witness trees stratified by ecoregion } \\
\text { and ecosite }\end{array}$ & $\begin{array}{l}\qquad \\
\text { 2. Forest communities from } 1983 \text { photo- } \\
\text { interpreted forest inventory minus } \\
\text { agricultural and intolerant hardwood } \\
\text { sites used to determine ecosite-forest } \\
\text { associations }\end{array}$ \\
\hline $\begin{array}{l}\text { 3. Species frequencies (\% of stems } \\
\text { recorded) calculated for all ecosites } \\
\text { within each ecoregion }\end{array}$ & $\begin{array}{l}\text { 3. Community frequencies (\% of forest } \\
\text { cover) calculated for all ecosites within } \\
\text { each ecodistrict }\end{array}$ \\
\hline$\downarrow$ & $\downarrow$ \\
\hline \multicolumn{2}{|c|}{ Adjustments to data to allow for comparison } \\
\hline $\begin{array}{l}\text { 4. Species frequencies lumped into } \\
\text { "forest communities" (Table 2) }\end{array}$ & $\begin{array}{l}\text { 6. Forest communities adjusted to allow } \\
\text { comparison with new Witness Tree } \\
\text { "forest communities"(Table 2) }\end{array}$ \\
\hline $\begin{array}{l}\text { 5. Witness tree "community" frequencies } \\
\text { compared with basal area data from } \\
\text { FDS Permanent Sample Plots for all }\end{array}$ & $\begin{array}{l}\text { 7. Potential Forest communities } \\
\text { compared with } 2000 \text { forest community } \\
\text { cover data derived from in Geographic } \\
\text { Information System. }\end{array}$ \\
\hline
\end{tabular}

Fig. 4. Flow diagram explaining manipulation of Witness Tree and Potential Forests data to allow for comparison with present forest composition.

\begin{tabular}{|c|c|c|c|c|c|c|c|c|c|c|}
\hline \multirow[t]{2}{*}{ Ecosite } & \multicolumn{2}{|c|}{ Spruce } & \multicolumn{2}{|l|}{ Fir } & \multicolumn{2}{|c|}{$\begin{array}{l}\text { Tolerant } \\
\text { Hardwood }\end{array}$} & \multicolumn{2}{|c|}{ Cedar } & \multicolumn{2}{|c|}{ Pine } \\
\hline & $\mathrm{W}$ & $\mathrm{P}$ & $\mathrm{W}$ & $\mathrm{P}$ & $\mathrm{W}$ & $\mathrm{P}$ & $\mathrm{W}$ & $\mathrm{P}$ & W & $\mathrm{P}$ \\
\hline 1: Dry, poor, softwood & $\uparrow$ & $\downarrow$ & $\uparrow$ & $\uparrow$ & $\downarrow$ & $\downarrow$ & $\downarrow$ & $\downarrow$ & $\downarrow$ & $\downarrow$ \\
\hline 2: Moist, poor, softwood & $\uparrow$ & $\downarrow$ & $\uparrow$ & $\uparrow$ & $\downarrow$ & $\downarrow$ & $\downarrow$ & $\downarrow$ & $\downarrow$ & $\downarrow$ \\
\hline 3: Wet, poor, softwood & $\uparrow$ & $\downarrow$ & $\uparrow$ & $\uparrow$ & $T$ & $\downarrow$ & $\downarrow$ & $\downarrow$ & $\downarrow$ & $\downarrow$ \\
\hline $\begin{array}{l}\text { 4: Dry, moderately rich, } \\
\text { mixedwood }\end{array}$ & $\uparrow$ & $\downarrow$ & $\uparrow$ & $\uparrow$ & $\downarrow$ & $\downarrow$ & $\downarrow$ & $\downarrow$ & $\downarrow$ & $\downarrow$ \\
\hline $\begin{array}{l}\text { 5: Moist, moderately rich, } \\
\text { mixedwood }\end{array}$ & $\uparrow$ & $\downarrow$ & $\uparrow$ & $\uparrow$ & $\downarrow$ & $\uparrow$ & $\downarrow$ & $\downarrow$ & $=$ & $\downarrow$ \\
\hline $\begin{array}{l}\text { 6: Wet, moderately rich, } \\
\text { mixedwood }\end{array}$ & $\uparrow$ & $\downarrow$ & $\uparrow$ & $\uparrow$ & $\downarrow$ & $\downarrow$ & $\downarrow$ & $\downarrow$ & $\uparrow$ & $\downarrow$ \\
\hline 6b: Wet, rich, hardwood & $\uparrow$ & $\downarrow$ & $\uparrow$ & 个 & $\downarrow$ & $\downarrow$ & $\downarrow$ & $\downarrow$ & $\downarrow$ & $\downarrow$ \\
\hline 7: Moist, rich, mixedwood & $\uparrow$ & $\downarrow$ & $\uparrow$ & $\uparrow$ & $\downarrow$ & $\boldsymbol{\uparrow}$ & $\downarrow$ & $\downarrow$ & $\uparrow$ & $\downarrow$ \\
\hline $\begin{array}{l}\text { 7c: Moist, rich, mixedwood } \\
\text { (calcareous) }\end{array}$ & $\uparrow$ & $\downarrow$ & $\uparrow$ & $\downarrow$ & $\downarrow$ & $\downarrow$ & $\downarrow$ & $\downarrow$ & $\downarrow$ & $\downarrow$ \\
\hline 8: Moist, rich, hardwood & $\uparrow$ & $=$ & $\uparrow$ & $\downarrow$ & $\downarrow$ & $\downarrow$ & $\uparrow$ & $=$ & $\uparrow$ & $\downarrow$ \\
\hline 9: Dry, moderately rich, hardwood & $\uparrow$ & $\downarrow$ & $\uparrow$ & $\downarrow$ & $\downarrow$ & $\downarrow$ & $=$ & $\downarrow$ & $\uparrow$ & $\downarrow$ \\
\hline
\end{tabular}

Fig.5. Direction of change from Witness Tree $(\mathrm{W})$ and Potential Forests (P) to present day for five forest communities in Ecoregion 5 (Continental Lowlands). $\uparrow$ $=$ Increase since historical account, $\downarrow=$ Decrease since historical account, $==$ No change. Witness tree frequency data were compared with 1993 FDS permanent sample plot (PSP) species frequency data (by basal area). Potential Forests frequency data were compared with the 1993 photo-interpreted forest inventory. same way as the witness tree data (Table 2). For comparison with potential forests data, forest community cover data, derived from 1993 aerial photos, were summarized by ecosite. Forest cover data for 1993 provide the most reasonable comparison with the Potential Forests results because both are based on forest cover information rather than sample plot data. Although direct comparison between the Potential Forests and Witness Tree results is problematic, by using this double comparison approach, we have determined whether the direction of change in community groups from historical times to the present is the same for each presettlement forest characterization methodology.

\section{Results and Discussion}

For the five common community types (spruce, fir, tolerant hardwood, cedar, and pine), the two methods detected the 
(a)

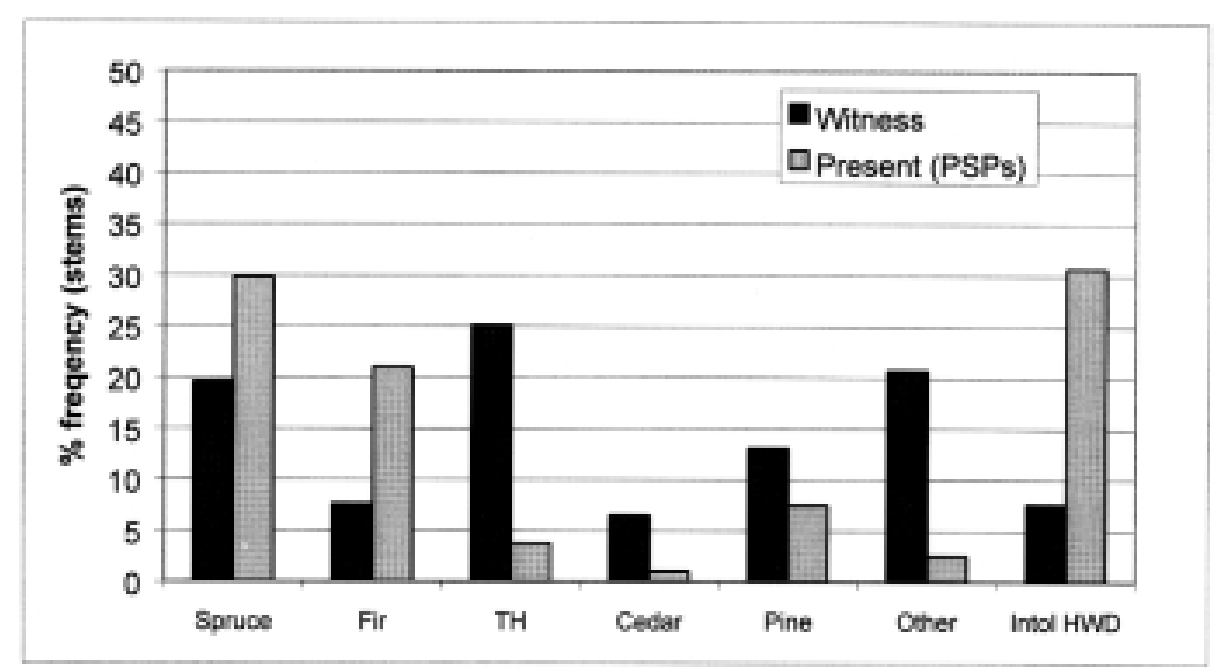

(b)

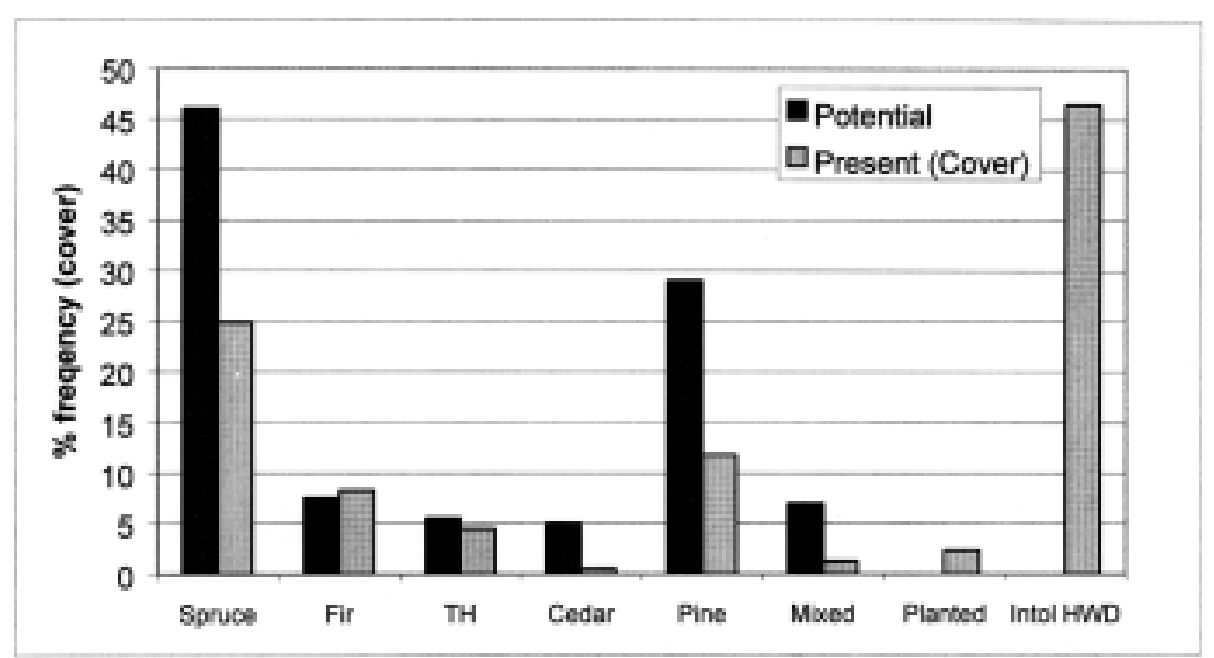

Fig. 6. Comparison of (a) Witness Tree data with present-day Forest Development Survey (FDS) data, and (b) Potential Forests with GIS forest cover data (1993) for ecosite 1 (dry, poor softwood), Continental Lowlands. same trends in $55.8 \%$ ecosite-forest community combinations (Fig. 5). The number of ecosites and community types examined makes generalization difficult, however, several commonalities and discrepancies in the results of the two methods are apparent. For the majority of ecosites in the Continental Lowlands, balsam fir frequencies were lower in the ELC analysis (Zelazny et al. 1997) and Witness Tree survey (Lutz 1997) than in the present-day forest (Fig. 6). This common result probably reflects a real change that has occurred over the past 200 years. Lutz (1997) suggested that this change is a result of high-grading practices. The demand for certain softwood tree species for lumber and the unmerchantability of fir resulted in gaps created by harvesting, leaving prime growing space for this species, which is well adapted to both early and late successional forest conditions. Successive waves of removal of other species over 200 years provided an opportunity for significant change in species composition. With each successive harvest wave, the frequency of the targeted species was reduced while the frequency of those remaining increased. Over a long period of time, balsam fir was the only coniferous species to escape harvesting pressure entirely. Blais (1983) suggested that budworm cycles, altered by pesticide spraying, may also have increased fir frequency. Interestingly, a decrease in fir was reported by the Potential Forests analysis in ecosites 1 , $7 \mathrm{c}, 8$, and 9 . This decline at the community level may reflect intensified stand-replacing harvests that "salvaged" budwormdamaged stands.

The frequency data for tolerant hardwood in ecosite 8 ("moist rich hardwood") are very similar for both presettlement analyses (Fig. 7). The high presettlement values contrast with the "present" forest data, which indicate much lower TH frequencies ( $8 \%$ and $22 \%$ for PSP and forest cover data, respectively). This is likely a reflection of the high degree of human intervention on these ecosites. Intolerant hardwood has increased as a result of the increased amount of stand-replacing harvest. To a lesser extent on this ecosite, old-field species such as white spruce have regenerated prolifically after the abandonment of agricultural land. 
(a)

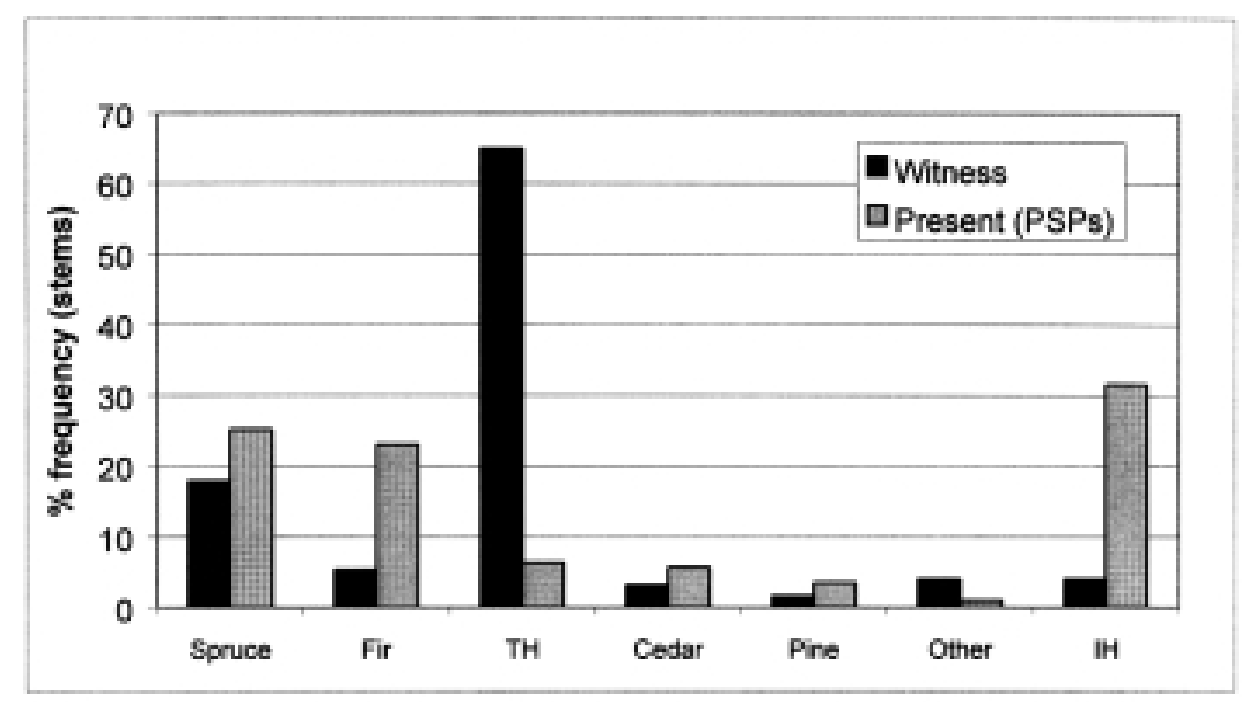

(b)

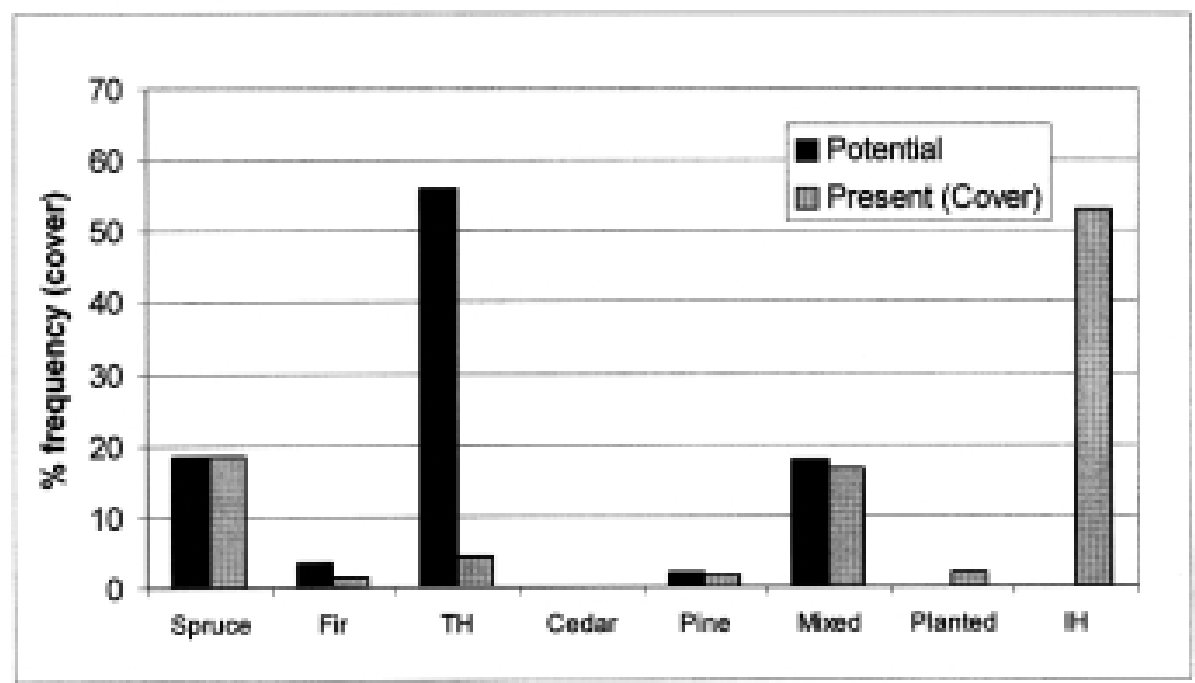

Fig. 7. Comparison of (a) Witness Tree data with present-day Forest Development Survey (FDS) data, and (b) Potential Forests with GIS forest cover data (1993) for ecosite 8 (moist, rich mixedwood), Continental Lowlands. Note similar frequencies of $\mathrm{TH}$ in both presettlement characterizations.
Both the witness tree and potential forests data indicate declines in tolerant hardwood for seven out of 11 ecosites (Fig. 5). However, the magnitude of decline is much more dramatic in relation to the witness tree data. The low frequency of tolerant hardwood in the Potential Forests analysis is particularly surprising in ecosites 7, 7c, and 6b-all of which the ELC working group reported to be characterized by rich hardwood or mixedwood (Fig. 8).

In all cases in the Continental Lowlands, except for hardwood ridge ecosites (8 and 9), spruce is reported to have declined since presettlement times according to the Potential Forests analysis, but to have increased according to the Witness Tree survey data. This might reflect a bias towards identifying "spruce" or "spruce-fir" stands in the 1984 aerial photo-interpretation process on which the potential forests data were based.

For most ecosites, Lutz (1997) and Zelazny et al. (1997) both reported higher frequencies of cedar than presently exists. This probably reflects human activities such as the clearing and draining of cedar swamps, and the high commercial demand for this species throughout the $19^{\text {th }}$ century (Lutz 1997).

In all ecosites, pine is reported to have declined since the presettlement era in the Potential Forests analysis. However, the witness tree data show increases in pine in four ecosites. This discrepancy may reflect the possible bias that white pine had been selectively removed before the witness tree surveys were carried out.

\section{Explanations for Discrepancies in Community Frequencies}

Despite some similarity in the direction of forest change reported by the two presettlement forest characterizations, there are clearly a number of important differences. There are several explanations for these incongruities. First, as mentioned above, the witness tree surveys were more common on more productive land. Lower quality ecosites may have been underrepresented by witness trees. The examination of witness tree 
(a)

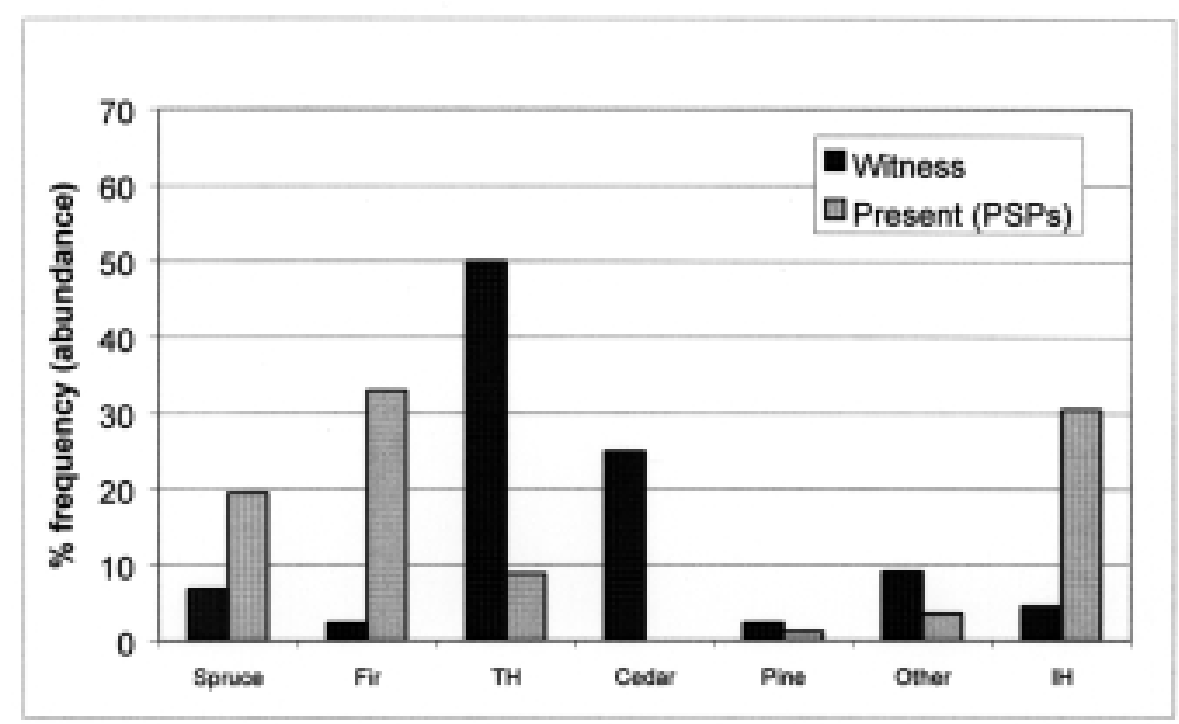

(b)

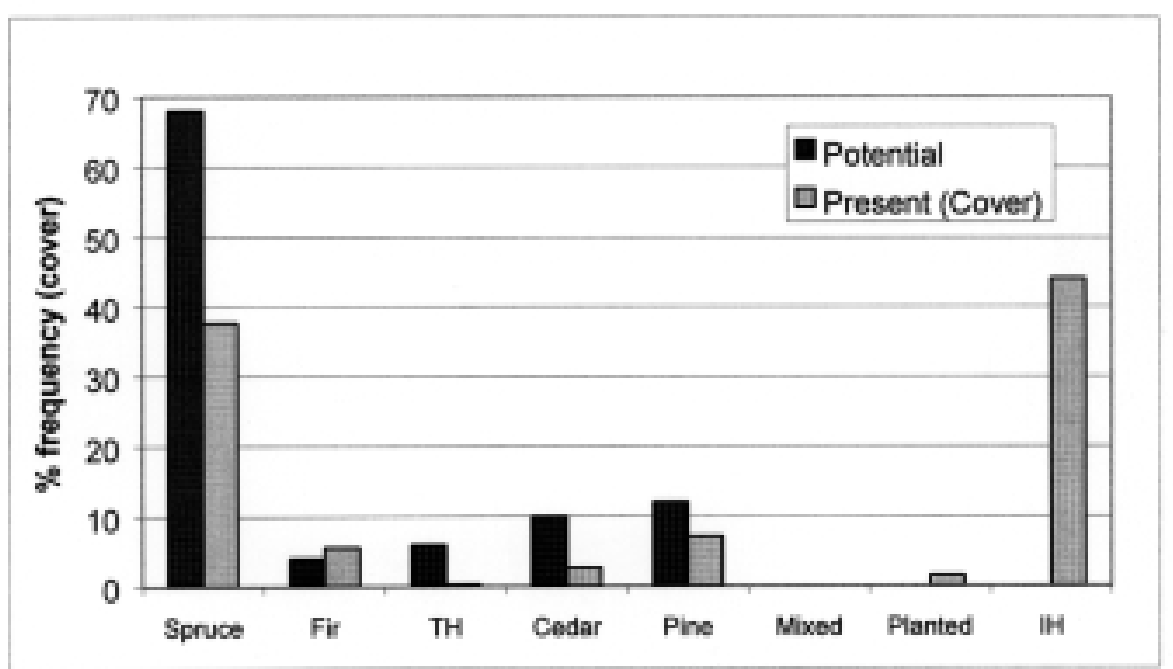

Fig. 8. Comparison of (a) Witness Tree data with present day Forest Development Survey (FDS) data, and (b) Potential Forests with GIS forest cover data (1993) for ecosite $6 b$ (wet, moderately rich mixedwood), Continental Lowlands. Note much higher frequencies of $\mathrm{TH}$ and much lower frequencies of spruce reported by the Witness Tree survey in comparison to the present-day forest. density in the range of ecosites reveals a correlation between density and land productivity ${ }^{3}$ (Fig. 9, 10). The scarcity of witness trees in the lower productivity ecosites may have resulted in a less statistically sound sample of these areas. Also, it is possible that surveys were biased toward apparently more productive sites within an ecosite. (For example, tolerant hardwood stands within ecosite 5 may have been more frequently surveyed than spruce-balsam fir stands). This would have been the case if the holdings were, on average, larger on poor quality ecosites.

A second possible cause for differing results is the fact that the Potential Forests approach is based on the ecosite clas-

\footnotetext{
${ }^{3}$ The ecosites rated as "rich" are 9, 8, 7, 7c, and 6b. "Moderately rich" ecosites include 4, 5, and 6. The "poor" ecosites are 1, 2, and 3 (Zelazny et al. 1997).
}

sification and only two major adjustments for human disturbance: removing (i) old fields and (ii) intolerant hardwood from the analysis. Thus, any other human disturbances that may have altered tree species composition, such as two centuries of selective removal of species in high demand or clearcut harvesting, are not accounted for in community-type frequencies. This could explain the lower frequencies of cedar and tolerant hardwood evident in Zelazny et al.'s (1997) results. These species, due to their poor regenerative capacity in open conditions (Burns and Honkala 1990), are not favoured by the large harvest openings that have been common in the Fundy Model Forest region (Zelazny and Veen 1997, Archambault et al. 1998).

A third probable cause for differing results relates to the poor direct comparability among data sets. As was emphasized above, Lutz (1997) examined individual species and related these to ecosites. Zelazny et al. (1997) examined the frequencies of community-type cover by ecosites. Thus, for example, it 


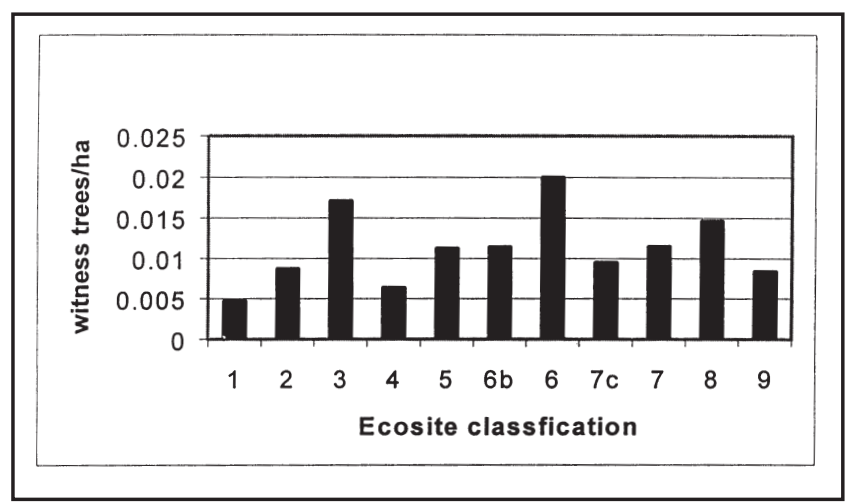

Fig. 9. Witness tree density in ecosites of the Continental lowlands.

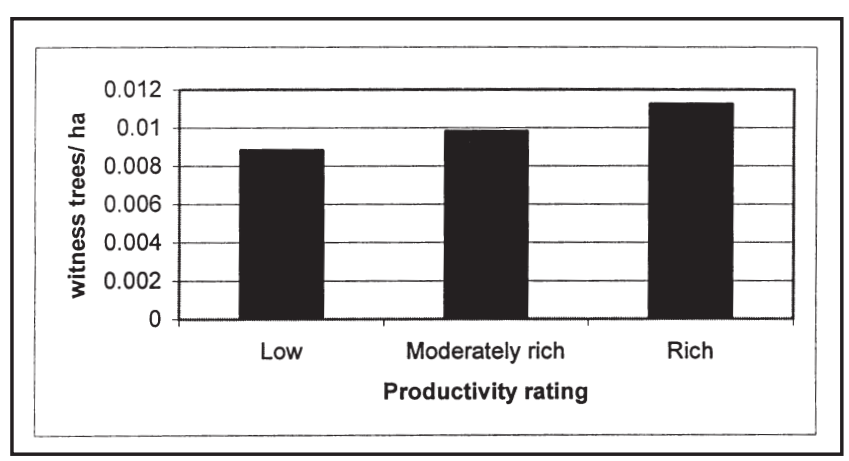

Fig. 10. Witness tree density in ecosites categorized by productivity class.

would be difficult to determine the proportion of tolerant hardwood witness trees that may actually have been part of a mixedwood community.

Differing abundances might not necessarily signify methodological weaknesses in either of the methods, but could reflect incongruous changes in tree species abundance at the individual tree vs. the community scale. For example, in ecosite 8 (moist, rich hardwood) cover of fir patches has declined slightly according to the Potential Forests analysis (Fig.5, Fig. 6). This change may be due to the practice of salvage harvesting budworm-damaged fir stands in the 1970s and 1980s. Conversely, the witness tree-1993 PSP comparison indicates that the number of individual fir trees has increased since presettlement. As mentioned above, this could reflect the practice of selective highgrading within stands for species other than fir over the past 200 years.

\section{Conclusion: Usefulness of Presettlement Characterization in Forest Management Planning}

The importance of presettlement forest characterization in forest management is controversial. Botkin (1990) argued that to strive towards a historical state is to deny the dynamic nature of forest ecosystems. Indeed, the tree species composition of New Brunswick's forests has changed due to processes unrelated to timber harvesting. Beech bark disease and Dutch elm disease, both introduced pathogens, have decreased the frequencies of beech and elm in our forests
(Forbes et al. 1998). Tree species have also been shown to migrate in response to changing climate (Davis 1983). Even without real and potential natural changes, humans have exerted such a powerful influence over the Fundy Model Forest region over the past two centuries that attempting a return to presettlement forest condition would be an infeasible goal.

However, there are many advantages to conserving the historical genetic and species diversity of trees. Most of these advantages relate to the rate of human-induced change, and the uncertainties associated with forest management outcomes. Tree species frequency is likely to have changed much more quickly over the past 200 years than it has at any other time in the period since post-glacial recolonization. It is possible that the characteristics of our forests are being altered more rapidly than many species' ability to adapt. Maintaining genetic diversity increases the probability that populations will be able to adapt to environmental change in the future. Thus, it is logical that we should attempt to maintain relative species and community abundances at least until we develop more detailed knowledge about the potentially crucial ecological roles played by these tree species and forest communities (Lindenmayer et al. 2000).

The comparative analysis of two presettlement forest characterizations has shown that, although some similarities in results are evident, some important differences exist. The question remains: "What information should be used as a guide to forest management?" Because each of the two approaches has methodological strengths and weaknesses, the best choice would seem to be to integrate the strengths of both. Each approach could be used to critically "cross check" frequencies suggested by the other.

Furthermore, because each method reports changes at different scales (individual vs. community), both have particular strengths in terms of their ability to guide forest management decisions. The Witness Tree method is well suited to provide information on the abundance of less common species. For example, within ecosite 6 (wet, moderately rich mixedwood) it is possible to determine an approximate presettlement frequency for eastern hemlock within other forest stands-a feat that would be difficult with a technique such as the Potential Forests analysis that uses relatively coarse aerial photography information as a basis. Managers striving to protect a species from eradication or to maintain the abundance of less common species within stands would be best served by the Witness Tree characterization for the formulation of guidelines and policy.

On the other hand, the Potential Forests approach allows for the examination of change in the frequency of whole forest communities. For example, it is possible to determine how "mixedwood" as a forest community has changed since presettlement. This would be impossible using witness tree accounts that provide no information on forest community groups. Managers seeking to recreate a historical proportion of forest communities within a landscape would thus find potential forests data the most informative approach.

To maintain "biodiversity" managers must be concerned with diversity at genetic, species, community and landscape scales (Noss and Cooperrider 1994). With the use of these two presettlement forest methodologies, managers have the capability to determine both the frequency of individual tree species, and forest communities at the landscape (ecoregion) scale. Such a dual approach to determining presettlement forest composition 
provides a benchmark for the frequencies of tree species and forest community types that existed before human beings began to exert widespread and rapid change on forest ecosystems in North America. Although we might not strive to replicate the precise species compositions reflected by these analyses, they can provide a guide to management so that we can maintain, or at least not eradicate species and community types that provide critical ecological services.

\section{Acknowledgements}

We would like to thank Thom Erdle, Graham Forbes, Dean Toole, Jamie Simpson and Caroline Simpson for their thoughtful comments and editorial review during the preparation and completion of this manuscript.

\section{References}

Archambault, L., J. Morissette, and M. Bernier-Cardou. 1998. Forest succession over a 20-year period following clearcutting in balsam fir yellow birch ecosystems of eastern Quebec, Canada. Forest Ecology and Management. 102 (1): 61-74.

Blais, J. 1983. Trends in the frequency, extent and severity of spruce budworm outbreaks in eastern Canada. Can. J. For. Res. 13: 539-547.

Botkin, D. 1990. Discordant Harmonies. A New Ecology for the Twenty-First Century. Oxford University Press.

Bourdo, E. 1956. A review of the General Land Office Survey and its use in quantitative studies of former forest. Ecology 37: 754-768. Burns, R. and D. Honkala. 1990. Silvics of North America. U.S.D.A. Washington, D.C.

CCFM. 1995. Defining Sustainable Management: A Canadian Approach to Criteria and Indicators. Canadian Council of Forest Ministers, Ottawa.

Clements, F.E. 1936. Nature and structure of climax. Journal of Ecology 24: 252-284.

Colpitts, M.C., S. Fahmy, J. MacDougall, T. Ng and V. Zelazny. 1995. Forest Soils of New Brunswick. New Brunswick Department of Natural Resources and Energy, Fredericton.

Davis, M. 1983. Holocene vegetational history of the Eastern United States. In H. Wright (ed.). Late Quarternary Environments of the United States. University of Minnesota Press, Minneapolis, MN.

Dyer, J.M. 2001. Using witness trees to assess forest change in southeastern Ohio. Can. J. For. Res. 31: 1708-1718.

Etheridge, P., K. Pugh, G. Watt, and M. Whelan. 1999. Criteria and Indicator Status Report 1999/2000. Natural Resources Canada. Forbes, G., H. Veen, V. Zelazny and S. Woodley. 1998. Ecological change in the Greater Fundy Ecosystem, In S. Woodley, G. Forbes, and A. Skibicki (eds.). State of the Greater Fundy Ecosystem. pp. 55-74. GFERG, University of New Brunswick, Fredericton, N.B.

Friedman S.K., P.B. Reich and L.E. Frelich. 2001. Multiple scale composition and spatial distribution patterns of the northeastern Minnesota presettlement forest. Journal of Ecology 89: 538-554.

Hansen, A.J., T. Spies, F. Swanson and J. Ohmann. 1991. Conserving biodiversity in managed forests: lessons from natural forests. BioScience 41(6): 382-392.

Hébert, D. and S. Boutin. 1998. Integrating strategies to retain ecological variability. In N.W.P. Munro and J.H.M. Willison (eds.). Linking Protected Areas with Working Landscapes Conserving Biodiversity. Proceedings of the Third International Conference on Science and Management of Protected Areas, 12-16 May, 1997. Wolfville, Canada. pp. 538-541. SAMPAA.
Hessburg, P.E., B.G. Smith and R.B. Salter. 1999. Detecting change in forest spatial patterns from reference conditions. Ecological Applications 9: 1232-1252.

Jackson S.M., F. Pinto, J.R. Malcolm and E.R. Wilson. 2000. A comparison of pre-European settlement (1857) and current (1981-1995) forest composition in central Ontario. Can. J. For. Res. 30: 605-612. Lindenmayer, D., C. Margules and D. Botkin. 2000. Indicators of biodiversity for ecologically sustainable forest management. Conservation Biology 14(4): 941-950.

Loo, J. 1994. Forest biodiversity assessment and monitoring in the Maritimes. In D. McKenney, R. Sims, M. Soul(, B. Mackey and K. Campbell (eds.). Towards a Set of Biodiversity Indicators for Canadian Forests: Proceedings of a Forest Biodiversity Indicators Workshop. Natural Resources Canada, Sault Ste. Marie.

Loucks, O.L. 1962. A Forest Classification for the Maritime Provinces. Proceedings of the Nova Scotian Institute of Science Vol. 25, Part 2.

Lutz, S. 1997. Pre-European Settlement and Present Forest Composition in King's County, New Brunswick, Canada. Master of Forestry Thesis, University of New Brunswick.

NBDNRE. 1986. Forest Development Survey. Fredericton, N.B. NBDNRE. 1996. Ecological Land Classification for New Brunswick: Ecoregion, Ecodistrict and Ecosite Levels. Fredericton, N.B.

Noss, R. and A. Cooperrider. 1994. Saving Nature's Legacy. Protecting and Restoring Biodiversity. Island Press, Washington, D.C. Oliver, C. and B. Larson. 1996. Forest Stand Dynamics. John Wiley and Sons, New York.

Remsoft Inc. 1996. FireNB. Fredericton, New Brunswick.

Rowe, J.S. 1959. Forest Regions of Canada. Bulletin 123, Dept. of Northern Affairs and Natural Resources, Forestry Branch. Ottawa, Canada.

Schnitzler, A. and F. Borlea. 1998. Lessons from natural forests as keys for sustainable management and improvement of naturalness in managed broadleaved forests. Forest Ecology and Management 109: 293-303.

Seymour, R. 1992. The red spruce-balsam fir forest of Maine: evolution of silvicultural practice in response to stand development patterns and disturbances. In M. Kelty, B. Larson and C. Oliver (eds.). The Ecology and Silviculture of Mixed-Species Forests. pp. 217-244. Kluwer Academic Publishers.

Wein, R. and J. Moore. 1977. Fire history and rotations in New Brunswick Acadian Forest. Can. J. For. Res. 7: 285-294.

Woodley, S. and G. Forbes (eds.). 1997. Forest Management Guidelines to Protect Native Biodiversity in the Fundy Model Forest. New Brunswick Cooperative Fish and Wildlife Research Unit, University of New Brunswick. 32 p.

Zelazny, V., H. Veen and M. Colpitts. 1997. Potential Forests of the Fundy Model Forest. Department of Natural Resources and Energy, Fredericton, N.B.

Zelazny, V. and H. Veen. 1997. The Acadian forest, past and present. In Proceedings of an Ecological Landscape Management Workshop, Fredericton, N.B., Canadian Woodlands Forum, Canadian Pulp and Paper Association, Oct. 1997, pp. 9-13. 